\title{
A GEOTECHNICAL STUDY ON THE CHARACTERISTICS OF SWELL-SHRINK SOILS IN KIBAHA, TANZANIA
}

\author{
Charles Lucian', Staffan Hintze ${ }^{2}$, Joseph J. Msambichaka ${ }^{3}$ \\ ${ }^{1}$ University College of Lands and architectural Studies (UCLAS), P.O. Box 35176, Dar es Salaam, Tanzania \\ ${ }^{2}$ Division of Soil and Rock Mechanics, Department of Civil and Architectural Engineering, \\ Royal Institute of Technology (KTH), Stockholm, Sweden. \\ ${ }^{3}$ College of Engineering and Technology, University of Dar es Salaam, P.O. Box 35131, Dar es Salaam, Tanzania
}

\begin{abstract}
The properties of Swell-shrink of the soils in Kibaha were studied. Geotechnical and mineralogical tests were carried out on disturbed and undisturbed samples recovered from trial pits at different locations. Using empirical relationships, the swelling potential of the soil was established in correlation with the soil plasticity limits and grain size analysis (clay contents). The average values for the plastic, liquid and linear shrinkage limits for soils were $22.2 \%, 60.7 \%$ and $14.5 \%$ respectively. The plasticity Index (PI) which is the difference between liquid limits and plastic limits ranges from $27 \%$ to $47.4 \%$ with an average of $38.5 \%$. The natural water content is very small ranging from $7 \%$ to $11 \%$ with an average of $9.6 \%$ which is smaller than the corresponding shrinkage limit.
\end{abstract}

Furthermore, the samples were tested for percentage of volume change in free swell tests and swelling pressure in onedimensional swell tests. The free swell and upward pressure were in the excess of $100 \%$ to $150 \%$ and $50 \mathrm{kPa}$ respectively. In addition, the coefficient of linear extensibility ranged from 0.09 to 0.14 signifying high to very high swellshrink potential.

Finally, the main clay mineral present in the sample was determined by running the X-ray diffraction (XRD) test. The $x$ ray diffraction scan indicated the presence of high proportion of clay minerals (smectite) in the soils.

Key Words: Swell-shrink soils, soil index properties, potential swell, montmorillonite (smectite)

\section{INTRODUCTION}

Swell-shrink soils are defined as those which exhibit large volume changes when wetted and large shrinkage when dried. Apart from the moisture change, the swell-shrink behaviour is controlled by the amount of clay minerals and soil structure. Investigations to determine the physical properties of soils of swelling-shrinking soils call for geological and topographical studies, and geotechnical and mineralogical tests of the soils from the area.

Over the past decade, many structures have been constructed in the Kibaha with little knowledge of the presence and effect of swell-shrink soils in the area. As a result many structures especially light weight structures are showing signs of damage in form of cracks. This study brings to light the fact that the soils in Kibaha harbour the swell-shrink properties thus calling for special attention when the construction is initiated.

This paper aimed at identifying the characteristics of swell-shrink soils in the case study. Geotechnical analysis was carried out by running the sieve analysis test, Atterberg limits (liquid limit, plastic limit, and shrinkage limit) tests and swelling tests. The soil consistency limits were correlated with clay contents to assess the degree of expansiveness of the soils.

Furthermore, the free swell was conducted followed by the coefficient of linear extensibility (COLE). The above tests were supplemented with X-ray analysis to determine the predominant clay minerals that tend to influence shrinkage and swelling properties of the soils in the area. Finally, the research recommendations were developed following the know-how of construction on expansive soils.

\section{GEOGRAPHY AND CLIMATIC CONDITIONS OF THE AREA}

The study area is positioned at an altitude $107 \mathrm{~m}$ above sea level and boarded approximately by geographical altitude of $06^{\circ} 35^{\prime} \mathrm{S}$ and $06^{\circ} 55^{\prime} \mathrm{S}$ and longitude of $38^{\circ} 45^{\prime} \mathrm{E}$ and $39^{\circ} 15^{\prime} \mathrm{E}$. This area has the climate with a contrast between humid subtropical region and semiarid region. It has two distinct seasons which are distinguished by duration of rainfall rather than by changes in temperature. The period of long rains is from March to May and that of short rains from October to December. The two seasons are separated by dry seasons; the hottest months falling between January and March and the coldest with minimum average of $21{ }^{\circ} \mathrm{C}$ coming 
between June and August. In the hot months, air and soil temperatures are high exceeding $30^{\circ} \mathrm{C}$ which results into extensive decrease of moisture in soil as well as desiccation of the soil surface.

\section{GEOLOGY}

The soils in this region comprise deposition of alternating sedimentary sequences consisting of mudstones, sandstones, lime-stones, shales, sand, gravel and vertebrate fossils (Mpanda, S., 1997). The sediments are considered as first phase of the sedimentary cycle dating from the late Mesozoic and early Cenozoic periods. The sediments were cemented together resulting into soils of high clay content. The soil that is exposed at the surface consists chiefly of sandy clay. It is typically normally consolidated, highly plastic and exhibits high swell potential when wet.

\section{GEOTECHNICAL SITE INVESTIGATION}

Geotechnical site investigation consisted of profile description and the collection of both disturbed and undisturbed samples. Four open trial pits measuring $2 \mathrm{~m}$ long and $1 \mathrm{~m}$ wide each were manually dug $3 \mathrm{~m}$

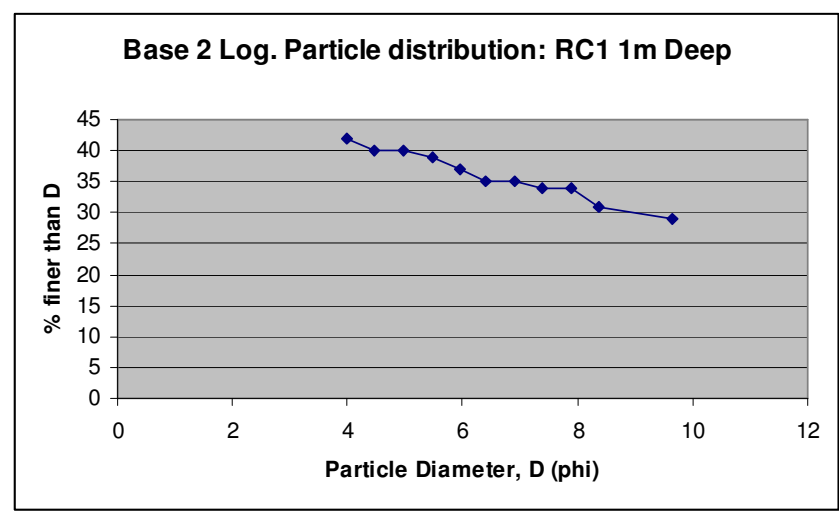

Figure 1: Base two logarithmic particle size distribution curves for 2 samples

The total unit weights were in the range between $1.4 \mathrm{~g} / \mathrm{cm}^{3}$ and $1.9 \mathrm{~g} / \mathrm{cm}^{3}$ with an average value of $1.6 \mathrm{~g} / \mathrm{cm}^{3}$ indicating that the soils were hard at the time of inspection.

\section{Consistency Limits}

A summary of laboratory test results for the soil samples is presented in Table 1 . The liquid limit (LL) varies from $50 \%$ to $69 \%$ and averages $60.7 \%$. The plastic limit (PL) is between $15 \%$ and $30 \%$ with an average value of $22.2 \%$. The plasticity Index (PI) deep in different representative locations. The samples were retrieved from the pits at well earmarked positions. The soil profile cross-sections show that the ground is dominated with clayey soils with interchanging proportional amount of sandysilt.

\section{LABORATORY TESTS TO CHARACTERISE THE SOILS}

Common index property tests to characterize the expansiveness of soils were carried out on 13 undisturbed samples collected from the trial pits. These included determination of clay contents, dry unit weight, water contents and Atteberg limits. The consistency limits are index properties plotted on the developed charts to indicate the degree of swell potential.

\section{Particle Size Analyses and Unit Weight}

The samples are predominantly course textured at all depths with predominance of sands. The grain size distribution indicate high proportion of sand followed by moderate amount of fines and small amount of granular deposits (Figure 1).

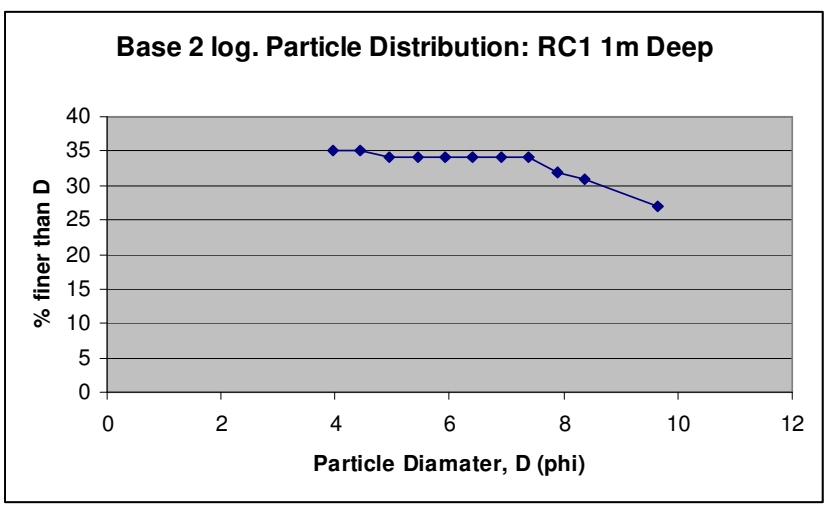

which is the difference between liquid limits and plastic limits ranges from $27 \%$ to $47.4 \%$ with an average of $38.5 \%$. The natural water content is very small ranging from $7 \%$ to $11 \%$ with an average of 9.6\% which is smaller than the corresponding shrinkage limit. The values of natural water content below shrinkage limit values indicate the state of intense dryness and desiccation of the clay at the period the observation was carried out. Addition of a very small amount of water to that soil in such state of high desiccation may induce high swell potential. 
Table 1: Physical Properties of Soil Samples

\begin{tabular}{|l|r|r|r|r|r|r|}
\hline & \multicolumn{1}{l|}{ Range } & Mean \% & \multicolumn{1}{l|}{ STD Error } & \multicolumn{1}{l|}{ STD } & \multicolumn{1}{l|}{ Skewness } & \multicolumn{1}{l}{ Kurtosis } \\
\hline Colloid & $22-39 \%$ & $31.2 \%$ & $1.1 \%$ & $4.2 \%$ & -0.3 & 0.6 \\
\hline Fines & $15-49 \%$ & $33.9 \%$ & $2.4 \%$ & $8.9 \%$ & -0.5 & 0.3 \\
\hline Sand & $42-71 \%$ & $58.5 \%$ & $2.1 \%$ & $7.7 \%$ & -0.6 & 0.3 \\
\hline Gravel & $1-16 \%$ & $7.5 \%$ & $1.3 \%$ & $5.0 \%$ & 0.1 & -1.4 \\
\hline Liquid Limit & $50-69 \%$ & $60.7 \%$ & $1.8 \%$ & $6.8 \%$ & -0.4 & -1.1 \\
\hline Plastic Limit & $15-30 \%$ & $22.2 \%$ & $0.8 \%$ & $3.1 \%$ & 0.3 & 4.4 \\
\hline Plasticity Index & $27-47.4 \%$ & $38.5 \%$ & $1.7 \%$ & $6.4 \%$ & -0.4 & -1.0 \\
\hline Shrinkage Limit & $11.1-17.1 \%$ & $14.5 \%$ & $0.4 \%$ & $1.7 \%$ & -0.3 & -0.2 \\
\hline Free Swell & $100-150 \%$ & $121.4 \%$ & $4.2 \%$ & $16.4 \%$ & 0.0 & -1.1 \\
\hline Activity & $0.9-2.1$ & 1.5 & 0.1 & 0.3 & -0.3 & -0.2 \\
\hline Moisture Content & $7-11 \%$ & $9.6 \%$ & $0.6 \%$ & $1.4 \%$ & -1.4 & 2.1 \\
\hline Bulk density & $1.4-1.9 \mathrm{~g} / \mathrm{cm}^{3}$ & $1.6 \mathrm{~g} / \mathrm{cm}^{3}$ & $0.1 \mathrm{~g} / \mathrm{cm}^{3}$ & $0.2 \mathrm{~g} / \mathrm{cm}^{3}$ & 0.9 & 0.6 \\
\hline Dry density & $1.3-1.7 \mathrm{~g} / \mathrm{cm}^{3}$ & $1.5 \mathrm{~g} / \mathrm{cm}^{3}$ & $0.1 \mathrm{~g} / \mathrm{cm}^{3}$ & $0.1 \mathrm{~g} / \mathrm{cm}^{3}$ & 0.8 & 0.5 \\
\hline
\end{tabular}

\section{Swelling Potential identification}

The most commonly used method to identify swelling potential is the indirect method where the influence of physical properties of the soils such as liquid limits, plasticity index and colloid contents are matched on established charts by different workers to indicate the degree of swell potential. In this study the plot of plastic index against liquid limit was according to Casagrande's plasticity chart (Figure 3) while that of plasticity index against colloids contents was according to Seed, et al. (1960) as shown in Figure 4. In both cases all samples possessed high to very high swell potential. A number of samples were tested, but to save on space, fewer samples are shown on Figures 3 and 4.

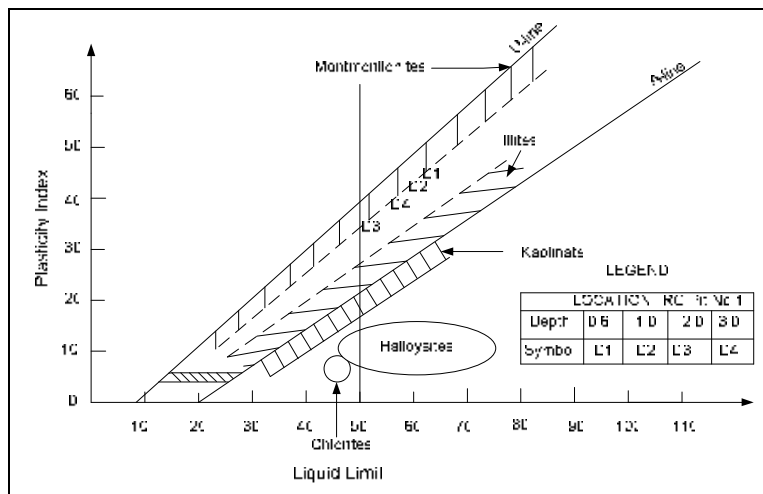

Figure 3: Plot of Clay Minerals at on Casagrande's Chart (Chleborad, A, F., et al, 2005)

\section{Free Swell Test}

The Swell Index or Free Swell test procedure is used to determine the general swelling characteristics of Soils. The soils specimens were tested to measure the free swell according to Holtz and Gibbs (1956) and standard free swell tests in oedometer cells. For the Free Swell Test the specimens are pulverized, put in test-tubes and the initial volumes are measured. Then water is added

to each test tube and the powder is allowed to swell freely. The degree of free swell is expressed as a percentage of the increase in volume, $\Delta V$, to the original volume, $V$, of the soil. The minimum and

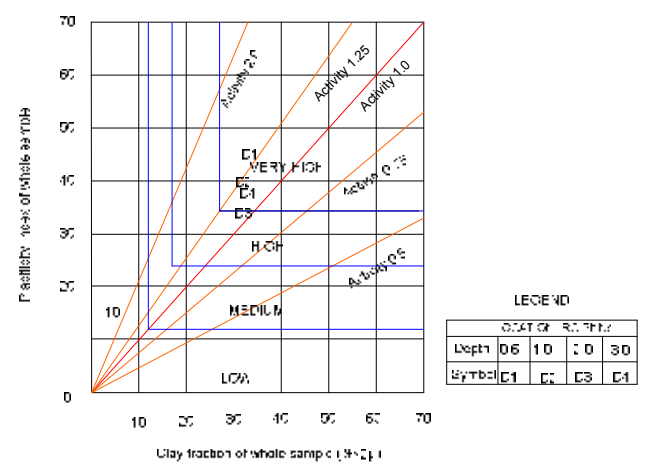

Figure 4: Plot of Clay Minerals at on a Chart for evaluation of potential expansiveness ( Seed, et al., 1960)

maximum swelling obtained from the free swell test are $100 \%$ and $150 \%$ respectively (Table 1 ). The results indicate that the soils are associated with clay which could swell considerably when wetted.

On the other hand, the test in oedometer was conducted on four undisturbed soil specimens. The undisturbed soil samples were cut at their in-situ moisture content, with minimum disturbance to the test specimens, and trimmed to fit the oedometer. The test specimens in the oedometer were saturated and brought to equilibrium under a small surcharge of about $1 \mathrm{kPa}$. The load on the specimen was increased periodically until the height of the specimen returned to origin. For each increment of load, the specimen is allowed to consolidate fully 
before the application of the next load. The amount of swell is recorded with the dial gauge and the maximum vertical stress necessary to attain original height of sample is the swelling pressure. The tests on Kibaha soils yielded a swell pressure between $45 \mathrm{kPa}$ and $50 \mathrm{kPa}$. This is envisaged to be greater than the counteracting pressure from the light weight structures.

\section{Potential for swelling by the coefficient of linear extensibility (COLE)}

The coefficient of linear extensibility (COLE) can be used to characterize the shrink-swell behaviour of soil (Nelson, J. D. and Miller, D. J., 1992). Undisturbed clods or cores are briefly immersed in a flexible resin and allowed to dry in laboratory. The resign coating must be impermeable to water but permeable to water vapour (Thomas, P. J., 1998). The clods are put to field tension of $33 \mathrm{kPa}$ or $10 \mathrm{kPa}$ tension (1/3- or 1/10-bar tension), weighed in air and water to determine weight and volume using Archimedes principle (i.e. Specific gravity= Mass in air $\div$ Loss of weight in water). The clods are brought to oven dryness, their weight and volume measured again. When coarse fragment are present, the COLE is calculated as follows: $C O L E_{w s}=\left[\frac{1}{C_{m} *\left(\frac{\gamma_{d 33<2 m m}}{\gamma_{d<2 m m}}\right)+\left(1-C_{m}\right)}\right]^{\frac{1}{3}}-1$

Where

$C O L E_{w s}=$ Coefficient of linear extensibility on a whole-soil base in $\mathrm{cm} \mathrm{cm}^{-1}$

$\gamma_{d 33<2 \mathrm{~mm}}=$ Dry Density at $33 \mathrm{kPa}$ water retention on a $<2 \mathrm{~mm}$ base $\left(\mathrm{g} / \mathrm{cm}^{3}\right)$

$\gamma_{d<2 m m}=$ Dry Density, oven-dry or air-dry, on a $<2 \mathrm{~mm}$ base $\left(\mathrm{g} / \mathrm{cm}^{3}\right)$
$C_{m} \quad=$ Coarse fragment (moist)

conversion factor.

$C_{m}$ is calculated as follows:

$C_{m}=\left[\right.$ Volume moist $<2 \mathrm{~mm}$ fabric $\left.\left(\mathrm{cm}^{3}\right)\right] /$

[Volume moist whole soil $\left(\mathrm{cm}^{3}\right)$ ]

or $C_{m}=(100-\mathrm{Vol}>2 \mathrm{~mm}) / 100$ where

Vol $>2 \mathrm{~mm}=$ Volume percentage of the $>2 \mathrm{~mm}$ fraction

If no coarse fragments, $C_{m}=1$, and the previous equation reduces to:

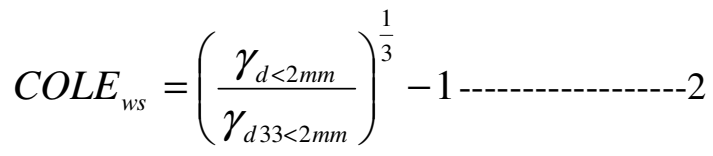

According to the calculated COLE, a range of soil swell-shrink potential can be distinguished based on data from Table 2.

Table 2: Ranges of COLE to determine soil swellshrink potential (Thomas, et al, 2000)

\begin{tabular}{|l|c|}
\hline $\begin{array}{l}\text { Soil swell-shrink } \\
\text { potential }\end{array}$ & COLE \\
\hline Low & $<0.03$ \\
\hline Moderate & $0.03-0.06$ \\
\hline High & $0.06-0.09$ \\
\hline Very High & $>0.09$ \\
\hline
\end{tabular}

Table 3 shows results of the coefficient of linear extensibility (COLEE) and bulk densities of a few samples selected from the case area. The results indicate that these soils are to be classified as high to very high expansive. The quantitative swell potential was also estimated by correlating the means of colloids content and the COLE as on Figure 5. Once again, the samples fell in the region of High to very high expansion potential

Table 3: Calculate Coefficient of linear extensibility (COLE) of samples from measured bulk densities.

\begin{tabular}{|l|l|r|r|r|r|}
\hline & & \multicolumn{2}{|c|}{ Bulk density } & & \\
\cline { 3 - 5 } Sample & Depth $(\mathrm{m})$ & Oven-Dry & $33 \mathrm{kPa}$ & COLE $(\mathrm{cm} / \mathrm{cm})$ & Clay Content $(\%)$ \\
\hline RCC1 & 1.0 & 1,87 & 1,32 & 0,12 & 34 \\
\hline RCC1 & 2.0 & 1,84 & 1,24 & 0,14 & 28 \\
\hline RCC1 & 3.0 & 1,83 & 1,23 & 0,14 & 32 \\
\hline RBB1 & 1.0 & 1,67 & 1,23 & 0,11 & 35 \\
\hline RBB1 & 2.0 & 1,61 & 1,25 & 0,09 & 33 \\
\hline RBB1 & 3.0 & 1,53 & 1,16 & 0,10 & 29 \\
\hline
\end{tabular}




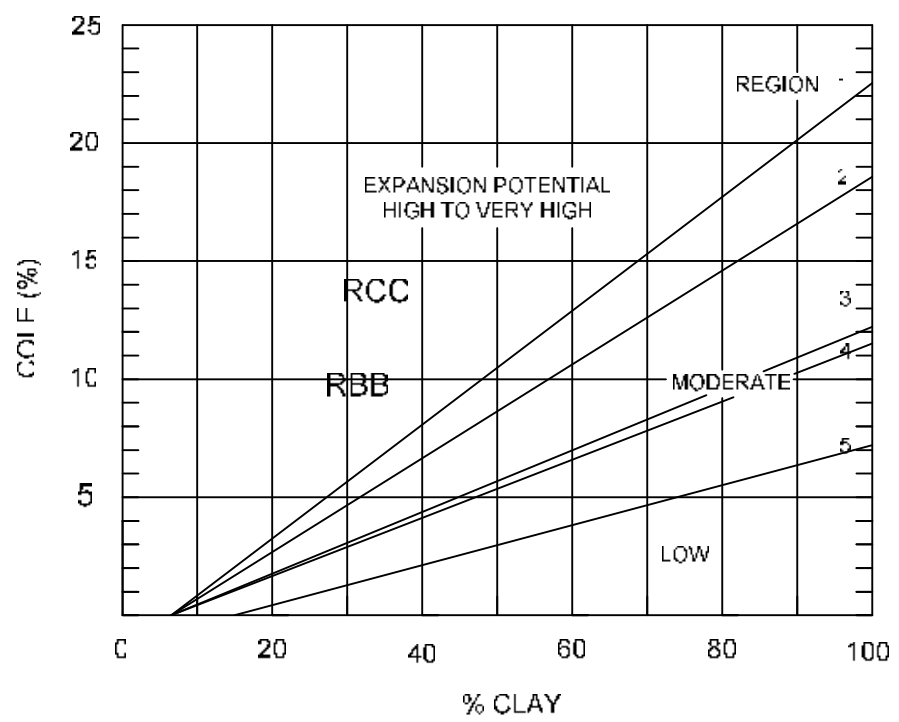

Figure 5: Expansion Potential as a Function of Colloids and COLE (Hardcastle, J. H., 2003)

\section{$X$-Ray Diffraction (XRD)}

For mineral identification, $x$-ray diffraction via powder method was carried using X-Ray Diffraction (XRD) techniques. Typical X-ray diffraction scans for soil sample from the case area are illustrated in
Figure 6. The results show that the soils are predominantly composed of smectite $(\sim 50 \%)$ with some traces of kaolinite. The high amount of smectite and less kaolinite in the soils indicates a high swelling potential.

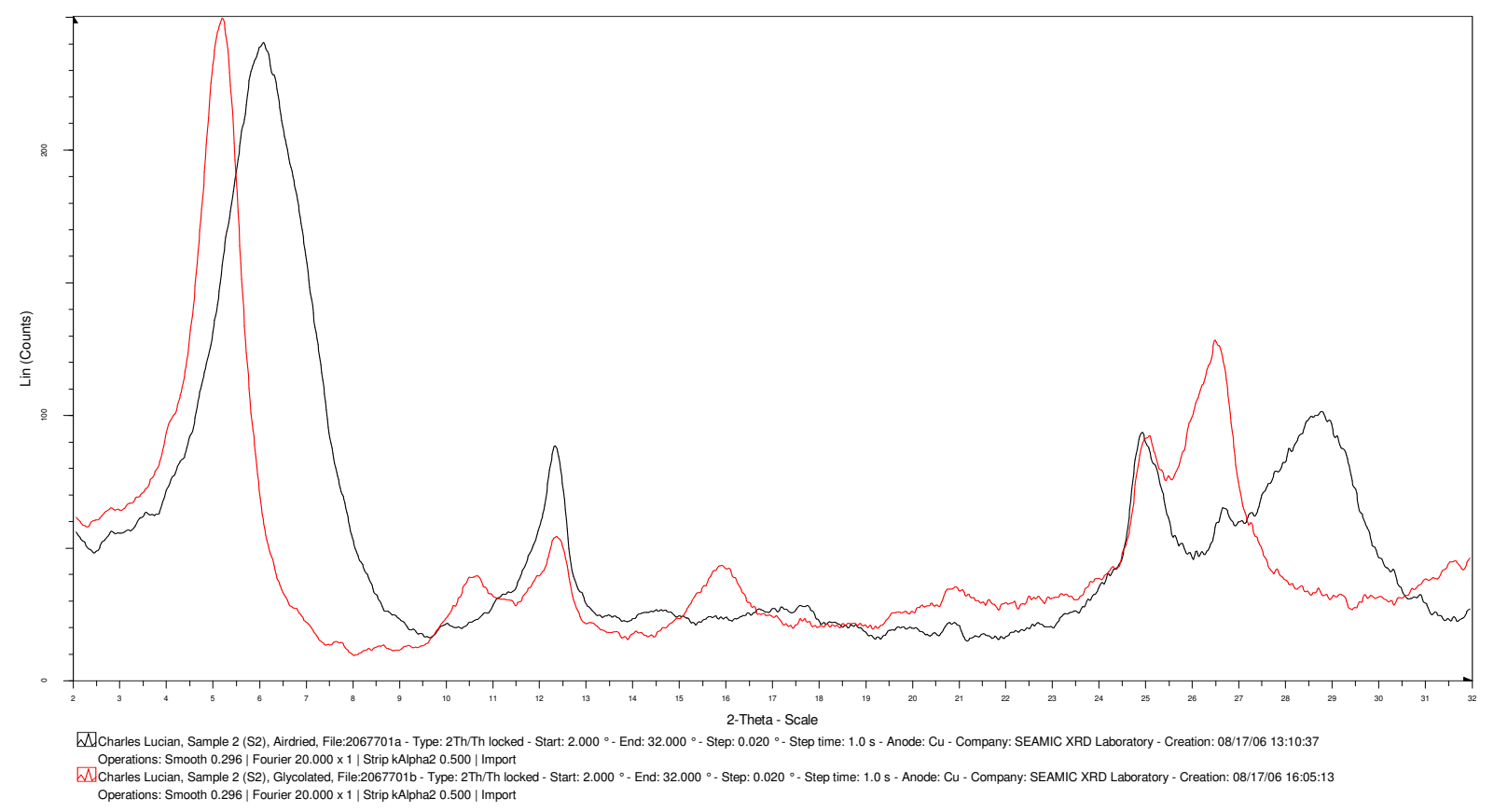

Sample2 (S2) - Clay Analysis

Figure 6: Diffractogram of a sample soil (Montmorillonite)

\section{CONCLUSIONS}

The soils in Kibaha have morphologic, physical and mineralogical properties typical of expansive soils because of the expanding nature of clay lattice (smectite). The geology and climatic conditions in the area favours the formation of smectite clay minerals in soils which are the main cause of ground heave problems. The smectite clay minerals of these expansive soils were developed during the late Mesozoic and early Cenozoic times. 
Identification of the propensity of a soil to shrink and swell before construction should be a key to proposing relevant measures to guard against building damages on expansive soils. This paper has presented few techniques which could be employed in the case study to identify the characteristics of swell-shrink soils.

\section{ACKNOWLEDGEMENTS}

The authors wish to acknowledge the help and assistance of the laboratory staff of the Dar es Salaam Institute of Technology (Tanzania), The Southern and Eastern African Mineral Centre (SEAMIC) and Division of Soil and Rock Mechanics at the Royal Institute of Technology (Sweden) during the field and laboratory tests. They are also grateful to Sida/SAREC for financial support.

\section{REFERENCES}

Chleborad A. F., Diehl, S. F., and Cannon, S. H., (2005) Geotechnical Properties of Selected Materials From the Slumgullion Landslide, http://pubs.usgs.gov/bul/b2130/Chapter11.html, as per $23^{\text {rd }}$ December, 2005

Hardcastle, J. H., (2003), Evaluation of Treatment of Expansive Volcanic Soils, University of Idaho, http://www.webs1.uidaho.edu/niatt/publications /ITD Reports/JH Report.pdf, accessed 16 March 2006.
Holtz, W.G., and Gibbs, H. J., (1956), Engineering Properties of Expansive Clays. Transactions, American Society of Civil Engineers, Vol. 121, 641-677pp.

McKenzie, N. J., Jacquier, D. W., Ashton, L. J., and Cresswell, H. P., (2000), Estimation of Soil Properties Using the Atlas of Australian Soils. CSIRO Land and Water. Technical report $11 / 00$

Mpanda, S., (1997), Geological development of the East Africa coastal basin of Tanzania, Stockholm contributions in Geology, Stockholm University, Department of Geology and Geochemistry, Stockholm, Sweden

Nelson, J. D., and Miller, D. J., (1992), Expansive soils: Problem and practice in foundation and pavement engineering, John Wiley and Sons, New York.

Seed, H. B., Mitchell, J. K., and Chan, C. K., (1960), The strength of compacted cohesive soils. Proceedings, ASCE Research Conference on Cohesive soils, Boulder, American Society of Civil Engineers, New York, 877-964pp.

Thomas, P. J., (1998), Quantifying Properties and Variability of Expansive Soils in Selected Map Units, PhD Dissertation, Virginia Polytechnic Inst. \& State Univiversity, USA, http://scholar.lib.vt.edu/theses/available/etd32398-73623/unrestricted/thomas.pdf, accessed $1^{\text {st }}$ March 2006 